\title{
EZH2 histone methyltransferase and induction of drug resistance to cytarabine in acute myeloid leukemia by 3-deazaneplanocin A
}

\author{
Richard L Momparler*, Sylvie Côté and Louise F Momparler \\ Département de Pharmacologie, Université de Montréal and Centre de recherche, Service d’hématologie/oncologie, CHU-Saint-Justine, Montréal, Québec, Canada
}

\begin{abstract}
Göllner et al. [6] reported that low levels of EZH2 in patients with acute myeloid leukemia (AML) correlated with a poor prognosis and predicted drug resistance. Using the MTS growth assay, which measures the enzymatic reduction of a colorimetric substrate, they observed that in vitro treatment of AML cells with 3-deazaneplanocin A (DZNep) induced drug resistance to cytarabine (ARA-C). Using a different growth inhibition assay, we observed that DZNep did not induce drug resistance to ARA-C and that this combination exhibited antineoplastic activity against AML cells that was greater than either agent alone. We conclude that their MTS assay gave faulty results, possibly due to the action of DZNep on gene expression in AML cells.
\end{abstract}

Chromatin alterations by enzymatic modifications of histones play an important role in the regulation of gene expression in cells. One of the key enzymes in this process is EZH2 histone methyltransferase that catalyzes the methylation of histone $\mathrm{H} 3$ lysine 27 (H3K27) to H3K27me, a repressive marker for gene expression [1]. Depending on the cell type, EZH2 was reported to function as either a tumor suppressor gene (TSG) or oncogene [1]. Several reports support the oncogene function of EZH2. High level of EZH2 confers a poor prognosis in patients with different malignancies [2,3]. Gain of function mutations that increase the enzymatic activity of EZH2 have been observed in patients with lymphomas [4]. The oncogenic action of EZH2 is to be silencing the expression of tumor suppressor genes and the genes that program differentiation [1].

In support of the TSG function of EZH2 are the loss-of-function mutations observed in patients with myelodysplastic syndrome (MDS) [5]. EZH2 inactivation in MDS is associated with a poor prognosis. The molecular mechanism of the TSG action of EZH2 is not fully understood. Göllner et al. investigated the possible TSG function of EZH2 in the development of AML [6]. This group quantitated the levels of EZH2 in bone marrow biopsies of AML patients at the time of diagnosis using immunostaining. They reported that low levels of EZH2 correlated with a poor prognosis in AML patients and responsible for drug resistance to tyrosine kinase inhibitors and cytotoxic drugs in AML.

In order to obtain additional data to support this hypothesis, they treated primary AML cells with 3-deazaneplanocin A (DZNep), an agent that reduces the level of EZH2 [1]. They determined the concentration of DZNep that inhibited the growth of the AML cells by $50 \%\left(\mathrm{IC}_{50}\right)$ using the MTS assay. In this assay, the MTS tetrazolium dye is converted to a colored compound by $\mathrm{NADH}$-dependent reductase enzymes, which is dependent on the number of viable cells [7]. They observed that DZNep increased significantly the $\mathrm{IC}_{50}$ value of ARA-C on the AML cells. Their experimental results are questionable since for some agents the MTS test can give erroneous results due to the increase in reductase activity induced by the agent under investigation
$[7,8]$. They proposed that DZNep treatment induced drug resistance to cytosine arabinoside (ARA-C, cytarabine) in the AML cells.

In order to verify the results of Göllner et al. [6], we performed a similar experiment using electronic cell counting and a colony assay to evaluate the antineoplastic activity of DZNep in combination with ARA-C on AML cells. Both these assays indicate that DZNep does not block the in vitro antileukemic action of ARA-C (Table 1). For example, DZNep $1 \mu \mathrm{M}$ and ARA-C $1 \mu \mathrm{M}$ reduced colony formation by the AML cells by 73.3 and $20.0 \%$, respectively, whereas in combination they exhibited an $86.6 \%$ reduction in colony formation. Our hypothesis to explain the difference of our data with the data of Göllner et al. is that reduction in the level of EZH2 in AML cells by DZNep possibly lead to increased expression of reductase enzyme activity that resulted in greater color formation by the MTS substrate. It is of interest to note that Göllner et al. [6] also observed that knock down of EZH2 by shRNA also exhibited similar results as the DZNep treatment. These observations suggest that reduction in the level of EZH2 by DZNep or shRNA increases the gene expression of reductase enzymes.

DZNep has an interesting potential for the treatment of AML. In preclinical studies, DZNep exhibits a potent inhibition of the proliferation of AML cells, both in vitro and in vivo [9]. In addition, DZNep in combination with the histone deacetylase inhibitor, panobinostat, or in combination with the inhibitor of DNA methylation,

*Correspondence to: Richard L Momparler, Service d'hématologie/ oncologie, CHU-Saint-Justine, 3175 Cote Sainte-Catherine, Montréal, Québec H3T 1C5, Canada, Tel: 51434549316140; Fax: 5143454801; E-mail: richard.1.momparler@umontreal.ca

Key words: EZH2, acute myeloid leukemia, drug resistance, 3-deazaneplanocin A, ARA-C

Received: August 27, 2018; Accepted: September 14, 2018; Published: September 19, 2018 
Table 1. Effect of DZNep on in vitro antileukemic action of cytarabine (ARA-C) on HL-60 myeloid leukemic cells

\begin{tabular}{|l|c|c|}
\hline Treatment $^{*}$ & $\begin{array}{c}\text { Loss of colony formation } \\
(\%) \\
(\text { mean } \pm \text { SEM) }\end{array}$ & $\begin{array}{c}\text { Growth inhibition (\%) } \\
\text { (mean } \pm \text { SEM) }\end{array}$ \\
\hline Group A $(\mathrm{n}=3)$ & $73.3 \pm 1.5$ & $65.2 \pm 0.5$ \\
\hline DZNep 1 $\mu \mathrm{M}$ & $20.0 \pm 1.5$ & $57.2 \pm 2.3$ \\
\hline ARA-C 1 $\mu \mathrm{M}$ & $86.6 \pm 1.4$ & $73.2 \pm 1.0$ \\
\hline DZNep 1 $\mu \mathrm{M}+$ ARA-C 1 $\mu \mathrm{M}$ & \multicolumn{2}{|l|}{} \\
\hline Group B $(\mathrm{n}=3)$ & $85.1 \pm 1.1$ & $69.4 \pm 2.7$ \\
\hline DZNep 5 $\mu \mathrm{M}$ & $20.0 \pm 1.4$ & $53.2 \pm 2.4$ \\
\hline ARA-C 1 $\mu \mathrm{M}$ & $90.7 \pm 0.8$ & $74.9 \pm 2.4$ \\
\hline DZNep 5 $\mu \mathrm{M}+$ ARA-C $1 \mu \mathrm{M}$ & &
\end{tabular}

"DZNep was added to medium at $0 \mathrm{~h}$ and ARA-C added at $24 \mathrm{~h}$. At $48 \mathrm{~h}$ the cells were counted, and 1,000 cells placed in soft-agar medium for colony formation determination on days 16-18 as described previously ${ }^{10}$. Statistical analysis: antileukemic action of DZNep 1 or $5 \mu \mathrm{M}+$ ARA-C $1 \mu \mathrm{M}>$ DZNep 1 or $5 \mu \mathrm{M}$ or ARA-C $1 \mu \mathrm{M}$; $\mathrm{p}<0.05$; (One-way ANOVA) for both growth and colony assays

decitabine, exhibits a remarkable synergistic antineoplastic action against AML cells $[9,10]$. In addition, DZNep in combination with decitabine also exhibited a remarkable synergistic activation of genes that suppress leukemogenesis in AML cells [11]. These reports indicate that DZNep is an interesting epigenetic agent that merits clinical investigation in patients with AML and other malignancies. The negative data published on DZNep by Göllner et al. [6] can hinder its development in cancer therapy. It is important that their experimental results be verified using a different assay to evaluate growth inhibition.

\section{Acknowledgments} Society.

This project was supported by a grant from the Canadian Cancer

\section{Disclosure of conflicts of interest}

The authors disclose no conflict of interest.

\section{References}

1. Lund K, Adams PD, Copland M (2014) EZH2 in normal and malignant hematopoiesis. Leukemia 28: 44-49. [Crossref]

2. Varambally S, Dhanasekaran SM, Zhou M, Barrette TR, Kumar-Sinha C, et al. (2002) The polycomb group protein EZH2 is involved in progression of prostate cancer Nature 419: 624-629. [Crossref]

3. Raaphorst FM, Meijer CJ, Fieret E, Blokzijl T, Mommers E, et al. (2003) Poorly differentiated breast carcinoma is associated with increased expression of the human polycomb group EZH2 gene. Neoplasia 5: 481-488. [Crossref]

4. Morin RD, Johnson NA, Severson TM, Mungall AJ, An J, et al. (2010) Somatic mutations altering EZH2 (Tyr641) in follicular and diffuse large B-cell lymphomas of germinal-center origin. Nat Genet 42: 181-185. [Crossref]

5. Khan SN, Jankowska AM, Mahfouz R, Dunbar AJ, Sugimoto Y, et al. (2013) Multiple mechanisms deregulate EZH2 and histone $\mathrm{H} 3$ lysine 27 epigenetic changes in myeloid malignancies. Leukemia 27: 1301-1309. [Crossref]

6. Göllner S, Oellerich T, Agrawal-Singh S, Schenk T, Klein HU, et al. (2017) Loss of the histone methyltransferase EZH2 induces resistance to multiple drugs in acute myeloid leukemia. Nat Med 23: 69-78. [Crossref]

7. Wang P, Henning SM, Heber D (2010) Limitations of MTT and MTS-based assays for measurement of antiproliferative activity of green tea polyphenols. PLoS One 5: e10202. [Crossref]

8. Ulukaya E, Colakogullari M, Wood EJ (2004) Interference by anti-cancer chemotherapeutic agents in the MTT-tumor chemosensitivity assay. Chemotherapy 50: 43-50. [Crossref]

9. Fiskus W, Wang Y, Sreekumar A, Buckley KM, Shi H, et al. (2009) Combined epigenetic therapy with histone methyltransferase EZH2 inhibitor 3-deazaneplanocin A and the histone deacetylase inhibitor panobinostat against human AML cells. Blood 114: 2733-2743. [Crossref]

10. Momparler RL, Idaghdour Y, Marquez VE, Momparler LF (2012) Synergistic antileukemic action of a combination of inhibitors of DNA methylation and histone methylation. Leuk Res 36: 1049-1054. [Crossref]

11. Momparler RL, Côté S, Momparler LF, Idaghdour Y (2017) Inhibition of DNA and histone methylation by 5-aza-2'-deoxycytidine (decitabine) and 3-deazaneplanocin-A on antineoplastic action and gene expression in myeloid leukemic cells. Front Oncol 7: 19. [Crossref]

Copyright: (C2018 Momparler RL. This is an open-access article distributed under the terms of the Creative Commons Attribution License, which permits unrestricted use, distribution, and reproduction in any medium, provided the original author and source are credited. 